\title{
IDENTIFYING THE INFLUENCE OF TECHNICAL RESOURCES KNOWLEDGE ON PRODUCT QUALITY REQUIREMENTS IN A GLOBAL ENGINEERING PROCESS
}

\author{
Gheorghe Ioan Pop ${ }^{1}$, Aurel Mihail Țîțu2,3, \\ ${ }^{1}$ S.C. Universal Alloy Corporation Europe S.R.L. Dumbravița 244A, Maramures, Romania, \\ 2 "Lucian Blaga" University of Sibiu, 10, Victoriei Street, Sibiu, România \\ 3 The Academy of Romanian Scientists, 54, Splaiul Independenței, Sector 5, Bucharest, Romania \\ Emails:popghitza@gmail.com,mihail.titu@ulbsibiu.ro
}

\begin{abstract}
The global engineering process in aerospace organizations is controlled by technically trained resources. Each structural product is designed and prepared for manufacture by design organizations in compliance with international design standards, 3D modeling and those specific to design organizations. These standards need to be known by industry organizations, namely the resources that work in manufacturing preparation processes and manufacturing cells as a starting point. In order to control the technical information that directly affects the quality of the products, it is necessary to control the way in which they are managed. In industrial organizations, the flow of information is based on defined processes and the links between them. A very high flow of information is required to generate deliverables. By assessing the level of knowledge, in direct relation to the requirements of the products, the quality of the products can be controlled. By assessing product requirements, that knowledge needed for processes and activities can be identified in order to manage them properly. The workload control technique used in industrial organizations is based on the principle of reporting demand on capacity. All these mentioned aspects are debated and argued based on their own points of view in the present study. The conclusions drawn lead to the identification of new fields of research in the approached field.
\end{abstract}

Keywords: Requirements, Resources, Global Engineering Process, Organization Knowledge, Deliverables, Product Requirements Management.

\section{Introduction}

The global engineering process - from organizations with activity in the aerospace industry and not only - is the main process that deals with the management of product quality requirements and their conversion into manufacturing requirements (figure 1) [1], [2].

The global engineering process is a collection of all the processes of an industrial organization responsible for the preparation of production documentation. These are the processes that manage the product design documentation and translate into the production documentation, the inspection / validation documentation. In addition, in this group of processes you can find processes that turn design data into a technical database to support quality and business processes.

Converting product quality requirements in manufacturing organizations involves:

- Quality requirements;

- Inspection requirements and

- Manufacturing requirements.
To identify the factors influencing the global process, in this research, we approached the process analysis from the perspective of the influence of the resources needed for this process and in terms of deliverables generated by each component process on the others.

The methods and techniques used by industry organizations to analyze and convert projected documentation into execution documentation are largely influenced by the technical intellectual capital of these organizations [3], [4]. The technical intellectual capital of industrial organizations consists of technical knowledge acquired through education, training and knowledge gained through experience in the field of work [5]. From the point of view of achieving quality products, both types of knowledge are required [6]. Thus, the global engineering process is controlled by technically trained resources - engineers, and in terms of experience, it is preferable to exist, but unfortunately it is not always available, and then it must be developed [7], [ 8]. 


\section{Identifying the Influence of Technical Resources on the Global Engineering Process Analyzed}

The development of technical knowledge, specific to certain types of products can be achieved through training and testing, based on the types of requirements that define the products [9], [10].

The matrix method for identifying product requirements is a first step in assimilating the types of technical knowledge needed to understand and implement the requirements in manufacturing processes [11].

The manufacture of structural components in aircraft, from the perspective of understanding the requirements, requires technical knowledge, software, process operation within organizations and communication skills (Figure 1).

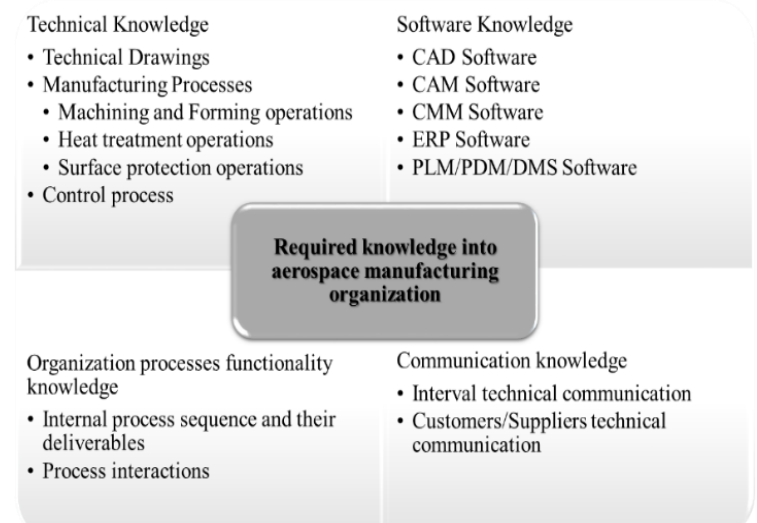

Figure 1: Types of knowledge required for industrial organizations in aerospace with specificity in the manufacture of structural components

Each structural product is designed and prepared for manufacture in compliance with international design standards, 3D modeling and standards specific to design organizations. These standards need to be known by industry organizations, namely the resources that work in manufacturing preparation processes and manufacturing cells as a starting point.

The manufacturing processes of structural components are similar to the processes used in all fields in which metal parts are manufactured. For this reason, knowledge of mechanical and chemical engineering is a minimum required. In the same way, the problem is posed on the control processes, which involve basic technical knowledge, process knowledge and knowledge on the methods and equipment of measurement and control.

Validation and certification of conformity of structural products in aircraft are an essential aspect that is part of the overall engineering process, as well as a final process.

Among these requirements can be mentioned:
- Reporting the values of the measured characteristics that are required to be prepared in specific electronic formats;

- Preparation and structuring of information from technology sheets, such as the mandatory presence of work instructions for each operation;

- Requirements for inspections in addition to those received from the customer, such as: measurement of process parameters of the equipment for their control, specific to certain products with high complexity.

At present, industrial organizations with a large volume of products in manufacturing and not only, have a fairly high level of quantity and complexity of requirements. In support of their management, industry organizations use CAD / CAM, CMM, ERP, PLM / PDM / DMS applications, which help in analyzing requirements and converting them into appropriate execution documentation.

The designed technical documentation of the products is made in CAD applications. They ensure the transfer of product requirements to CAM and CMM applications, using ERP, PLM, PDM and DMS support applications.

Having the technical and software knowledge, the resources must also know the specific stages of each process as defined in the quality management system, through specific procedures and instructions [12], [13].

In order to analyze the influencing factors of the global process of converting the designed technical documentation into technical execution documentation, we identified all deliverables in this process. These deliverables, in some cases, are considered inputs in some component processes, and in this sense, we have developed a matrix in order to highlight the main factors with the greatest influence on each deliverable (Table 1).

The most important influencing factors on the quality of each deliverable, which were observed in the manufacturing processes are:

a) Technical knowledge - "C-technical";

b) Software knowledge - "C-soft";

c) Planning knowledge - "C-planning";

d) Knowledge of the internal process - "C-process";

e) Capabilities in terms of software applications "App".

The factors mentioned above were identified by analyzing each activity within each process in terms of the possibility of performing that activity. The infrastructure of the industrial organization is not considered in this analysis, considering it to exist.

An example of the analysis of processes and activities is presented in Table 1, where we identified the type of knowledge needed to perform each activity and its motivation.

Addressing the factors influencing the activities is necessary due to the impact they have on the product [14], [15]. 
Thus, if this process is analyzed, that of receiving and registering documentation, it is observed that there are two activities that require technical knowledge, specific to aerospace products.

Table 1. The matrix of the activities of the process of receiving the technical documentation and the consciences

\begin{tabular}{|c|c|c|c|c|c|c|}
\hline $\begin{array}{l}\text { Proc. } \\
\text { Seq. }\end{array}$ & $\begin{array}{c}\text { Process } \\
\text { descriptio } \\
n\end{array}$ & $\begin{array}{l}\text { Activ. } \\
\text { Seq. }\end{array}$ & $\begin{array}{l}\text { Activity } \\
\text { Desc. }\end{array}$ & Knowledge code & $\begin{array}{l}\text { Knowledge } \\
\text { description }\end{array}$ & Knowledge example \\
\hline \multirow{9}{*}{1} & \multirow{9}{*}{$\begin{array}{l}\text { Technical } \\
\text { document } \\
\text { s receiving } \\
\text { and } \\
\text { registering }\end{array}$} & 1.1 & Task Planning & C-Planning & $\begin{array}{l}\text { Planning } \\
\text { Knowledge }\end{array}$ & $\begin{array}{l}\text { Knowledge regarding } \\
\text { method of mange task list } \\
\text { with due dated, status, } \\
\text { estimated and actual time. }\end{array}$ \\
\hline & & 1.2 & $\begin{array}{l}\text { Access to } \\
\text { customer } \\
\text { documentation } \\
\end{array}$ & C-Soft & $\begin{array}{l}\text { Software } \\
\text { Knowledge }\end{array}$ & $\begin{array}{l}\text { Knowledge regarding web } \\
\text { portal access using tokens. }\end{array}$ \\
\hline & & 1.3 & $\begin{array}{l}\text { Product } \\
\text { identification }\end{array}$ & C-Technical & $\begin{array}{l}\text { Technical } \\
\text { Knowledge }\end{array}$ & $\begin{array}{l}\text { Knowledge regarding } \\
\text { recognition of a Airbus, } \\
\text { Boeing, etc. product as per } \\
\text { document number pattern }\end{array}$ \\
\hline & & 1.4 & Files download & C-soft & $\begin{array}{l}\text { Software } \\
\text { Knowledge }\end{array}$ & $\begin{array}{l}\text { Operation system } \\
\text { knowledge }\end{array}$ \\
\hline & & 1.5 & $\begin{array}{l}\text { Transfer } \\
\text { locally }\end{array}$ & C-Process & $\begin{array}{l}\text { Internal } \\
\text { Processes } \\
\text { Knowledge } \\
\end{array}$ & $\begin{array}{l}\text { Intranet network and rules } \\
\text { regarding IT policy. }\end{array}$ \\
\hline & & 1.6 & $\begin{array}{l}\text { Internal } \\
\text { communicatio } \\
\mathrm{n} \text { regarding file } \\
\text { transfer and } \\
\text { registering }\end{array}$ & C-Communication & $\begin{array}{l}\text { Language } \\
\text { Knowledge }\end{array}$ & $\begin{array}{l}\text { Knowledge regarding } \\
\text { emails wording for } \\
\text { technical information as } \\
\text { short possible using } \\
\text { specific terms. }\end{array}$ \\
\hline & & 1.7 & $\begin{array}{l}\text { File register } \\
\text { into PLM } \\
\text { software } \\
\end{array}$ & C-soft & $\begin{array}{l}\text { Software } \\
\text { Knowledge }\end{array}$ & $\begin{array}{l}\text { Knowledge of how to use a } \\
\text { PLM software. }\end{array}$ \\
\hline & & 1.8 & $\begin{array}{l}\text { Documents } \\
\text { sorting by type } \\
\text { and product }\end{array}$ & C-Technical & $\begin{array}{l}\text { Technical } \\
\text { Knowledge }\end{array}$ & $\begin{array}{l}\text { Technical document } \\
\text { recognition as per internal } \\
\text { work instruction or } \\
\text { customer guidelines. }\end{array}$ \\
\hline & & 1.9 & $\begin{array}{l}\text { Email } \\
\text { confirmation of } \\
\text { task complete }\end{array}$ & C-Communication & $\begin{array}{l}\text { Language } \\
\text { Knowledge }\end{array}$ & $\begin{array}{l}\text { Knowledge regarding } \\
\text { internal communication of } \\
\text { task finishing. }\end{array}$ \\
\hline
\end{tabular}

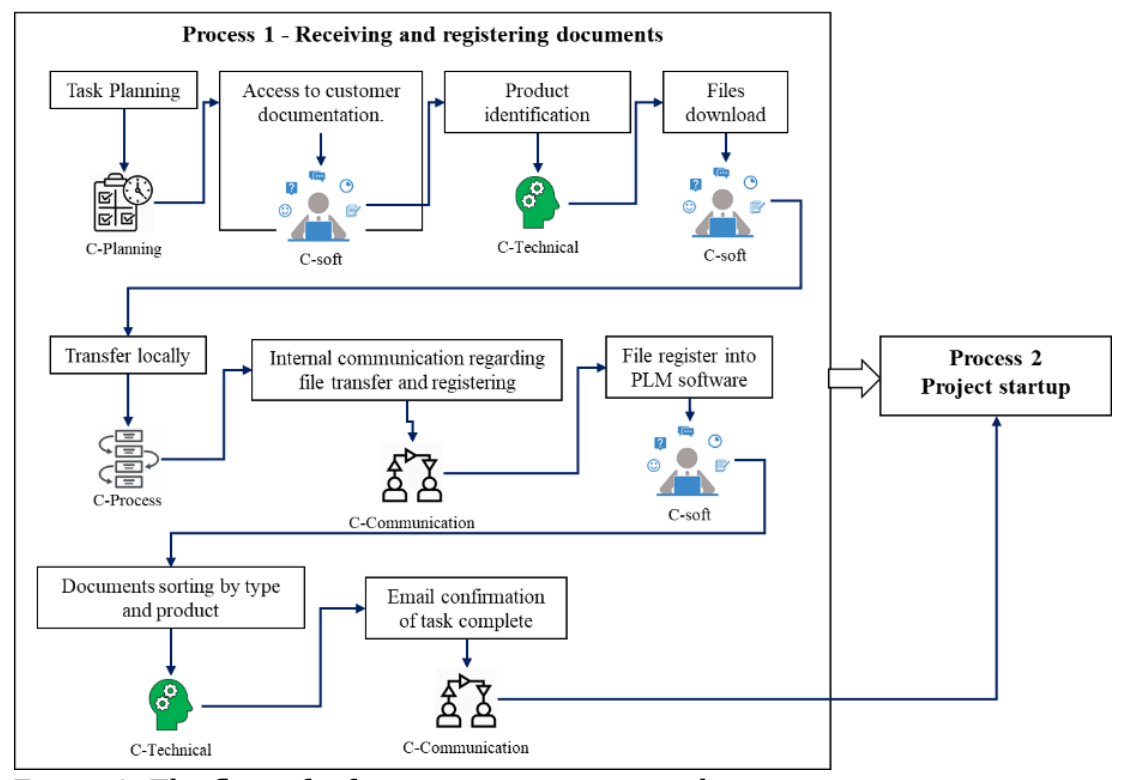

Figure 2: The flow of information in a process when carrying out its activities 
Figure 2 shows that each activity is performed by resources using different knowledge, without which the process could not continue

In order for the process to begin, knowledge of planning activities and time is minimally required. Some of the knowledge needed to carry out this process is not directly related to the products that are made but have a significant influence on the quality of the product on the activities that manage product information.

In order to control the technical information that directly affects the quality of the products, it is necessary to control the way in which they are managed.

By assessing the level of knowledge, in direct relation to the requirements of the products, the quality of the products can be controlled. By assessing product requirements, that knowledge needed for processes and activities can be identified in order to manage them properly.
Once the knowledge needed to manage product quality requirements is established, control of deliverables generated by the overall process needs to be done.

In order to create the necessary controls for deliverables, we must first analyze how the deliverables influence the whole process and finally, the quality of the products made.

\section{Influence of Identified Deliverables on the analyzed Global Engineering Process - Methods and Techniques of Process Data Analysis}

Table 2 presents the matrix of each component process of the global engineering process, in its current sequence with all the deliverables necessary for the manufacture of structural products within an industrial organization in aerospace.

Table 2. Matrix distribution of the level of influence of deliverables in the global engineering process

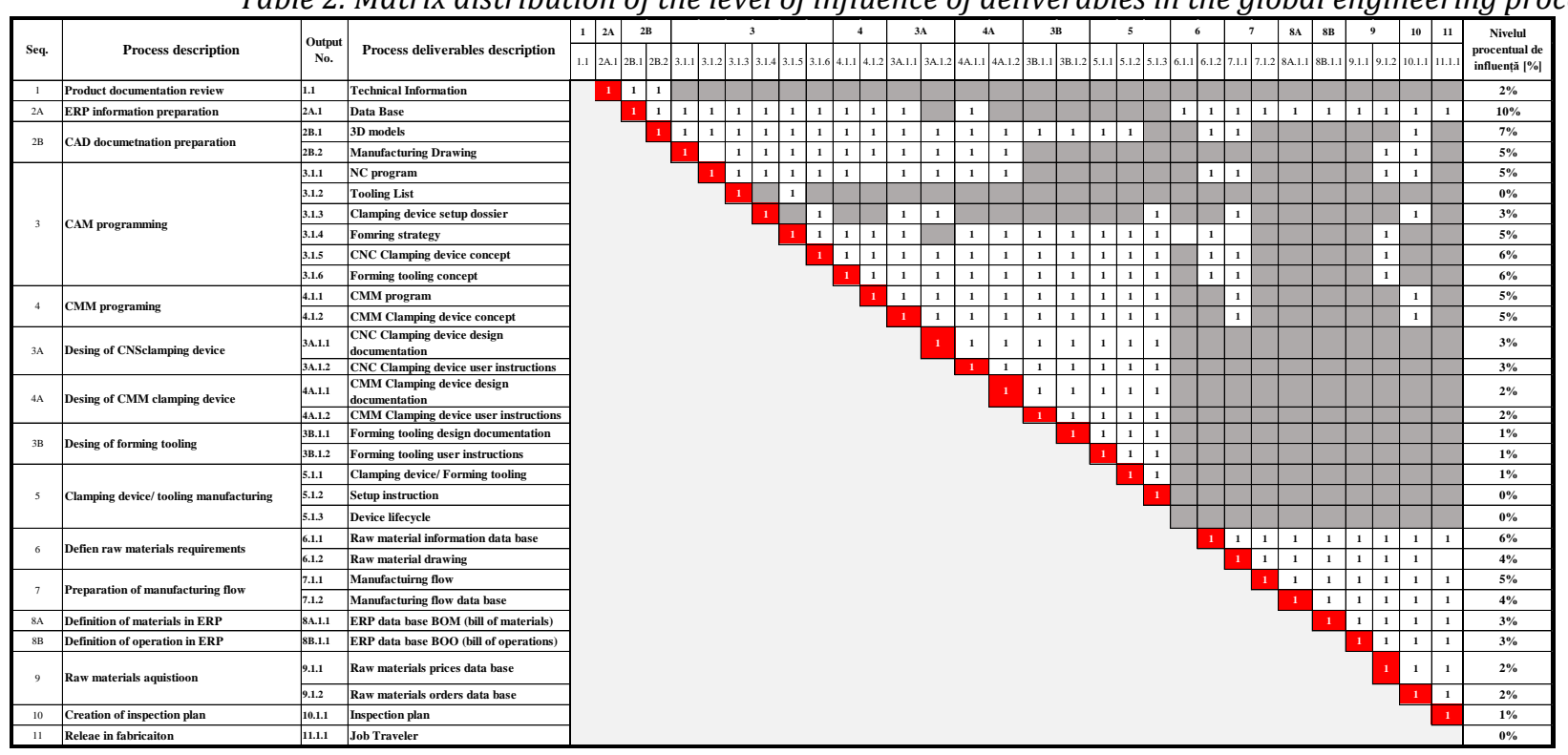

The level of impact calculated as a percentage, on the whole global process, is given by the interaction of each deliverable on the others, during the process. Thus, the deliverable that is considered as input for most deliverables can be considered as deliverable with the greatest impact on the whole process.

Analyzing the number of interactions of each deliverable on the others, we found that the deliverable called "ERP database" has the greatest influence on all deliverables.

This influence is given by the central position of this deliverable (figure 3) within the technical data management system. The correctness of the database plays a key role in the quality of products, with the possibility of generating non-compliant products only by entering or modifying information in the form of text.
In second place is the 3D model of the product, due to the fact that this deliverable has the requirements with the highest volume that define the entire requirements produced more precisely the designed requirements.

In industrial organizations, the flow of information is based on defined processes and the links between them. A very high flow of information is required to generate deliverables. When connecting all deliverables, given the influence matrix, it can be seen that once the technical information received from the customer is transferred to the database, the whole process revolves around this source of information (Figure 4). 


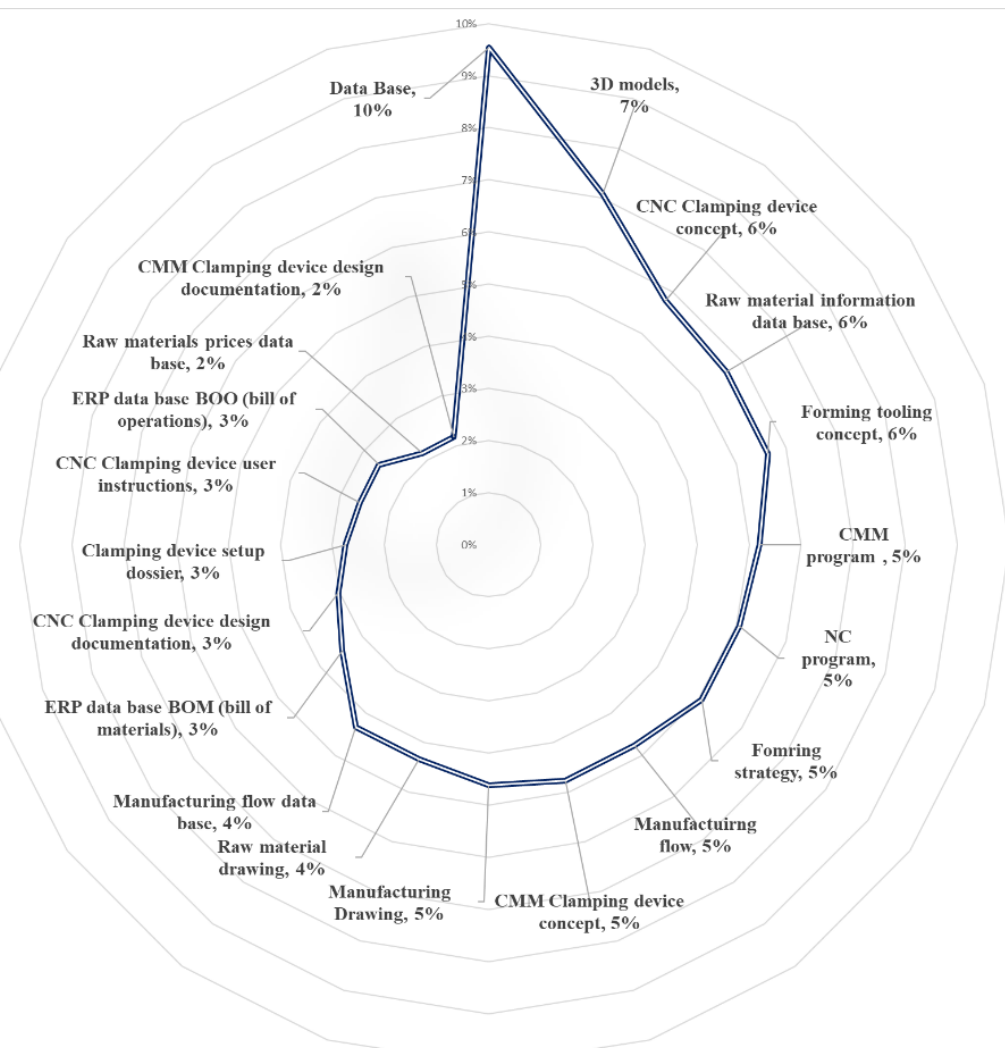

Figure 3: The "spider" diagram - deliverable with the greatest influence in the global process

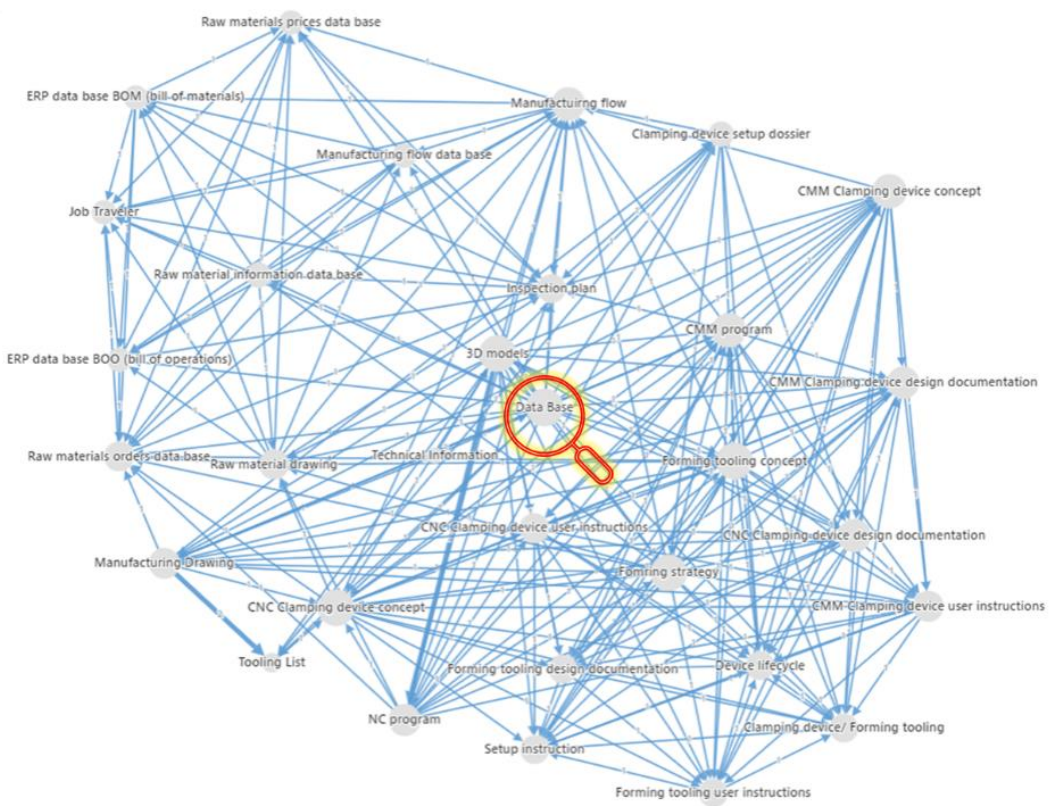

Figure 4: Deliverable's connections in the global process

Each process, regardless of its purpose or place in industrial organizations in aerospace industry, generates data that can be analyzed for the purpose of:

- To monitor the compliance of the process with the quality management system;

- To monitor the level of quality of process deliverables;

To control the workload and compliance with the planning of the functioning of organizations.
The specific quality audit processes are the processes that evaluate through audit reports, questionnaires and evaluations, the conformity with the procedures and instructions corresponding to the analyzed process, in the daily activities of the organization.

The results of these audits and questionnaires represent process data that can be used for management analysis or improvement projects. Such data can be considered: 
- The number of nonconformities and their type that help the organization to understand the possible opportunities for process improvement or even the lack of important process activities.

- Knowledge assessment questionnaires in the analyzed process that give a lot of data that can be analyzed in order to identify gaps or areas for improvement.

Monitoring the level of quality of process deliverables in aerospace are assigned based on quality targets, defined at the level of quality policies of organizations.

These are measured by checking each deliverable during the process or when using it in other processes.

The ratio between the total number of noncompliant deliverables and the total number of process-delivered deliverables is very commonly used in industrial organizations. This result is identified in industrial organizations as a key process indicator. The target value of this indicator is zero. The higher the value, the higher the number of corrective and improvement actions.

The control of the workload and the observance of the work plan of the manufacturing organizations is the control. This is most commonly encountered due to the visible drilled financial impact.

The workload control technique used in industrial organizations is based on the principle of reporting demand on capacity (Figure 5).

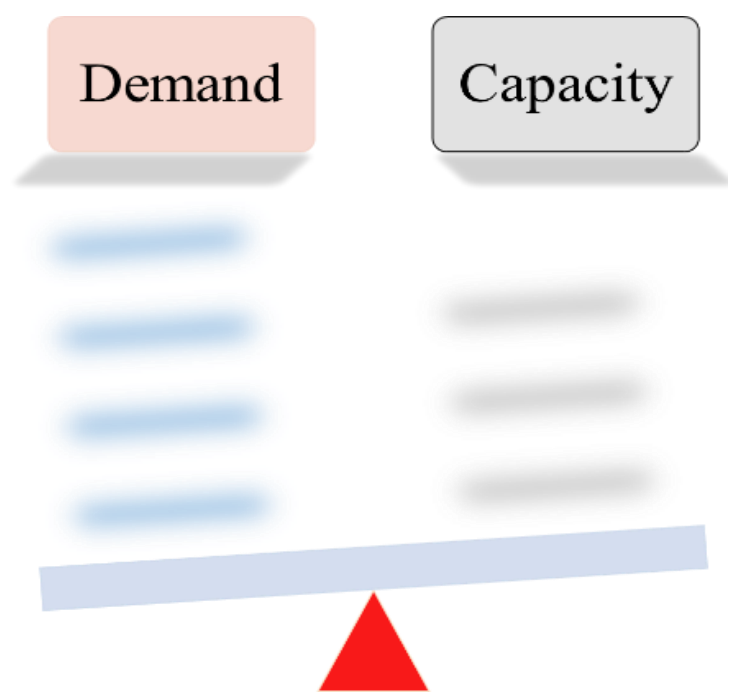

Figure 5: Manufacturing demand vs. capacity

In aerospace organizations and not only, at some point, the demand appears to be much higher than the capacity of the process.

This situation can be observed before it happens or when it is too late. In order to be able to observe these deficits, each department in the organization prepares a capacity model, being able to confirm or plan the availability of capacity so that the planned revenues of the organization are not affected.

\section{Conclusions}

The importance of evaluating product requirements results when the shortcomings of industrial organizations are identified from the implementation phase of the requirements.

The use of the global requirements analysis model helps industry organizations to assess all product requirements and allocate the relevant resources to meet them.

Establishing the indicators of influence, from the perspective of the resources that manage the process, represents an own contribution. Thus, the identification of all types of knowledge necessary to manage the requirements in the engineering process allows the development of a training plan for the resources involved in this process.

Capacity models are all the more efficient the more frequently they are updated with information on all the activities necessary to carry out the processes.

When the demand for products is greater than the capacity, some organizations have to adapt the internal processes so that with an existing capacity of resources to manage a volume of products, respectively of much higher requirements. All this can be achieved only through detailed analyzes of both product requirements and the capacity and capabilities of organizations.

A research direction involves the development of the matrices of influence of the deliverables of the global engineering process within the process and on the related processes, in order to identify the need to develop the component activities of the process and the human resources that perform these activities.

Also, worth noting would be the development of the matrix of influence of requirements on activities, respectively on knowledge of resources in order to develop specific training plans related to product requirements for human resources involved in this process, complementary to the knowledge generally applicable in the processes. engineering acquired through specific educational processes.

\section{References}

[1] Rojo, J.; Abollado, E.; Bamforth, P.; Challenges and Benefits of Digital Workflow Implementation in Aerospace Manufacturing Engineering, Procedia CIRP, Volume 60, Pages 80-85, Publiseh: 2017.

[2] Wu, TH.; Wu, F.; Liang, CJ.; et al.; A virtual reality tool for training in global engineering collaboration. Univ Access Inf Soc 18, 243-255 Publiseh: 2019. 
[3] Alblawi, M. Nawab; Alsyaari, A.; Application of systems engineering approach in senior design projects," 2018 IEEE Global Engineering Education Conference (EDUCON), pp. 1151-1160, Publiseh: 2018.

[4] Queiruga-Dios et al.; Evaluating engineering competencies: A new paradigm," 2018 IEEE Global Engineering Education Conference (EDUCON), pp. 2052-2055, Publiseh: 2018.

[5] Kassotaki, O.; Explaining ambidextrous leadership in the aerospace and defense organizations, European Management Journal, Volume 37, Issue 5, Pages 552-563, Publiseh: 2019.

[6] N'Cho, J.; Contribution of talent analytics in change management within project management organizations The case of the French aerospace sector, Procedia Computer Science, Volume 121, Pages 625-629, Publiseh: 2017.

[7] Arpentieva, M.; Duvalina 0.; Gorelova, I.; Intersubjective management in aerospace engineering, MATEC Web Conf., 102 01002, Publiseh: 2017.

[8] Gao, J.; Bernard, A.; An overview of knowledge sharing in new product development. Int J Adv Manuf Technol 94, 1545-1550, Publiseh: 2018.

[9] Elsouri, M.; Gao, J.; Simmonds, C.; Martin, N.; A design for manufacturing methodology using defects knowledge for aerospace product manufacturing. Proceedings of the Institution of Mechanical Engineers, Part B: Journal of Engineering Manufacture. Publiseh: April 2021.

[10] El Souri, M.; Gao, J.; Owodunni, O.; Simmonds, C.; Martin, N.; Improving Design for Manufacturing implementation in knowledge intensive collaborative environments: An analysis of organisational factors in aerospace manufacturing," 2017 IEEE Technology \&
Engineering Management Conference (TEMSCON), 2017, pp. 448-454, Publiseh: 2017.

[11] Parthasarathy Garre, V.V.S.; Nikhil Bharadwaj, P.; Shiva S.; Munigala Harish, M.; Sai D.; Applying lean in aerospace manufacturing, Materials Today: Proceedings, Volume 4, Issue 8, Pages 8439-8446, Publiseh: 2017.

[12] Masten, Scott E.; Meehan, James W. Jr.; Snyder, E.A.; The Costs of Organization." Journal of Law, Economics \& Organization 7, no. 1, pages 1-25, Publiseh: 1991.

[13] Mas, F.; Racero, J.; Oliva, M.; Morales-Palma, D.; Preliminary ontology definition for aerospace assembly lines in Airbus using Models for Manufacturing methodology, Procedia Manufacturing, Volume 28, Pages 207-213, Publiseh: 2019.

[14] Proulx, M.; Gardoni, M.; Methodology for Designing a Collaborative Business Model - Case Study Aerospace Cluster. In: Nyffenegger F., Ríos J., Rivest L., Bouras A. (eds) Product Lifecycle Management Enabling Smart X. PLM 2020. IFIP Advances in Information and Communication Technology, vol 594. Springer, Publiseh: 2020.

[15] Amladi, P.; HR's guide to the digital transformation: ten digital economy use cases for transforming human resources in manufacturing", Strategic HR Review, Vol. 16 No. 2, pp. 66-70, Publiseh: 2017. 